\title{
Rice yield, nitrogen utilization and ammonia volatilization as influenced by modified rice cultivation at varying nitrogen rates
}

\author{
Limei $\mathrm{Zhao}^{1,2}$, Lianghuan $\mathrm{Wu}^{1^{*}}$, Cunjun Dong ${ }^{3}$, Yongshan $\mathrm{Li}^{4}$ \\ ${ }^{1}$ Ministry of Education Key Laboratory of Environmental Remediation and Ecosystem Health, College of Environmental and \\ Resource Sciences, Zhejiang University, Hangzhou, China; *Corresponding Author: finm@zju.edu.cn \\ ${ }^{2}$ College of Ecology and Environmental Science, Inner Mongolia Agricultural University, Huhhot, China \\ ${ }^{3}$ College of Agriculture \& Biotechnology, Zhejiang University, Hangzhou, China \\ ${ }^{4}$ Cotton Research Institute, Shanxi Academy of Agricultural Sciences, Yuncheng, China
}

Received 15 March 2010; revised 5 April 2010; accepted 10 April 2010.

\begin{abstract}
Field experiments were conducted in 2006 to investigate the impacts of modified rice cultivation systems on: grain yield, $\mathrm{N}$ uptake, ammonia volatilization from rice soil and $\mathrm{N}$ use efficiency (ANUE, agronomic $\mathrm{N}$ use efficiency; and PFP, partial factor productivity of applied $\mathrm{N}$ ). The trials compared rice production using modified methods of irrigation, planting, weeding and nutrient management (the system of rice intensification, SRI) with traditional flooding (TF). The effects of different $\mathrm{N}$ application rates $(0,80$, $160,240 \mathrm{~kg} \mathrm{ha}^{-1}$ ) and of $\mathrm{N}$ rates interacting with cultivation methods were also evaluated. Grain yields ranged from 5.6 to $6.9 \mathrm{t} \mathrm{ha}^{-1}$ with SRI, and from 4.0 to $6.1 \mathrm{t} \mathrm{ha}^{-1}$ under TF management. On average, grain yields under SRI were $24 \%$ higher than that with TF. Ammonia volatilization was increased significantly under SRI compared with TF and the average total amount of ammonia volatilization loss during the rice growth stage under SRI was $22 \%$ higher than TF. With increases in application rate, $\mathrm{N}$ uptake by rice increased, and the ratio of $\mathbf{N}$ in the seed to total $\mathbf{N}$ in the plant decreased. Furthermore, results showed that higher ANUE was achieved at a relatively low $\mathrm{N}$ fertilizer rate $\left(80 \mathrm{~kg} \mathrm{ha}^{-1} \mathrm{~N}\right)$ with SRI. Results of these studies suggest that SRI increased rice yield and $\mathbf{N}$ uptake and improved ammonia volatilization loss from rice soil compared with TF. Moreover, there were significant interactions between $\mathrm{N}$ application rates and cultivation methods. We conclude that it was the most important to adjust the amount of $\mathbf{N}$ application under SRI, such as reducing the amount of $\mathrm{N}$ application. Research on effects of $\mathbf{N}$ fertilizer on rice yield and environmental pol-
\end{abstract}

lution under SRI may be worth further studying.

Keywords: Ammonia Volatilization; N Use Efficiency; Paddy Soil; Rice Yield; The System of Rice Intensification

\section{INTRODUCTION}

Nitrogen $(\mathrm{N})$ is the most important nutrient in irrigated rice production [1], and current high yields of irrigated rice are usually associated with large applications of fertilizer $\mathrm{N}$ [2] . China is currently the world's largest consumer of nitrogen fertilizers, accounting for 35\% of the global $\mathrm{N}$ fertilizer consumption [3], and about 7\% $\mathrm{N}$ was applied to irrigated rice [4]. Nitrogen use efficiency for rice is lower about $30-35 \%$ and with $\mathrm{N}$ losses up to $>$ $50 \%$ in China [5]. The unique condition of the paddy can promote $\mathrm{N}$ losses through denitrification, ammonia volatilization and leaching, and $\mathrm{N}$ losses not only lead to decrease in $\mathrm{N}$ fertilizer efficiency but also to soil, water and atmospheric pollution. Therefore, the measurement and assessment of $\mathrm{N}$ losses and increased $\mathrm{N}$ use efficiency have been of great significance for sustainable agriculture and environmental protection. Ammonia volatilization is the major process of $\mathrm{N}$ losses in irrigated rice, accounting for $0.41-40 \%$ of applied $\mathrm{N}$ as urea in China [6]. Ghosh and Ravi reported that ammonia volatilization losses in flooded soil ranged from negligible amounts to $60 \%$ of applied N [7]. The impact of ammonia volatilization losses on environmental quality has attracted a great deal of attention $[6,8]$.

In addition, irrigation plays a critical role in the ability of the rice sector to expand production to meet continually growing demand [9] since about $75 \%$ of rice production in the world comes from irrigated lowland rice fields [10]. China's 31.7 million ha of rice fields account for about $20 \%$ of the world's rice area and produce about 
$35 \%$ of total rice production [11]. However, fresh water for irrigation is becoming scarce because of increasing competition from urban and industrial demand [12-14]. Water resource limitations threaten the sustainability of irrigated rice systems in many countries, and water-saving rice cultivation methods are urgently needed to keep up with future food demands. Water-saving rice cultivation is important for rice production systems in the future.

A water-saving rice cultivation method known as the System of Rice Intensification (SRI) has been introduced into China from Madagascar where rice productivity is reportedly increased by simultaneously modifying several practices in rice cultivation [15]. With SRI, changes in standard management practices include: transplanting very young seedlings at the 2-3 leaf stage; having just one seedling per hill with wider spacing in a square pattern rather than rows; maintaining non-flooded soil conditions during the vegetative stage and very shallow irrigation after flowering; soil-aerating hand weeding; and application of large quantities of organic manure $[15,16]$.

SRI alters the environment for growing rice with no standing water during the vegetative growth period and only a thin layer of water on the field $(1-2 \mathrm{~cm})$ from panicle initiation until 10-15 days before harvest. These practices may be influence on nutrient form in soil and nutrient uptake and utilization by rice. Lower nitrogen efficiency with conventional plant/soil/nutrient management and high nitrogen losses from the soil/plant system, adversely affecting environmental quality, has attracted a great deal of attention. However, there is little information about what happens (specifically, $\mathrm{N}$ use efficiency and $\mathrm{N}$ losses as ammonia) with SRI practices. The objective of this study was to evaluate the impact of different rice cultivation methods and nitrogen fertilization rates on rice yield, $\mathrm{N}$ uptake, and $\mathrm{N}$-use efficiency and ammonia loss.

\section{MATERIALS AND METHODS}

\subsection{Site Description}

Located in the northern part of Zhejiang Province, eastern China, field experiment was conducted on the farm of Zhejiang University, Huajia Chi Campus in Hangzhou $\left(30^{\circ} 16^{\prime} \mathrm{N}, 120^{\circ} 12^{\prime} \mathrm{E}\right)$. The elevation is $4.3 \mathrm{~m}$. At the experimental site, the Hungson paddy soil (clay loamy typic-hapli-stagnic anthrosol) has a $\mathrm{pH}$ of 6.8 , organic matter of $11.2 \mathrm{~g} \mathrm{~kg}^{-1}$, available $\mathrm{N}$ of $104.8 \mathrm{mg} \mathrm{kg}^{-1}$, Olsen-P of $83.6 \mathrm{mg} \mathrm{kg}^{-1}$, and available $\mathrm{K}$ of $65.2 \mathrm{mg} \mathrm{kg}^{-1}$.

\subsection{Experimental Design, Fertilization and Cultural Practices}

The field experiment utilized a split-plot design with cultivation methods as main plots (traditional flooding = $\mathrm{TF}$, or system of rice intensification $=\mathrm{SRI}$ ), and $\mathrm{N}$ rates as subplots, all with three replications. The subplots $\left(5.5 \mathrm{~m} \times 4.2 \mathrm{~m}=23.1 \mathrm{~m}^{2}\right)$ of the main TF and SRI plots received, respectively, either $0 \mathrm{~kg} \mathrm{~N} \mathrm{ha}{ }^{-1}, 80 \mathrm{~kg} \mathrm{~N}^{-1}$, $160 \mathrm{~kg} \mathrm{~N} \mathrm{ha}^{-1}$ or $240 \mathrm{~kg} \mathrm{~N} \mathrm{ha}^{-1} .60 \%$ of the total $\mathrm{N}$ application as basal fertilizer (on May 19) was applied (as urea) one day before transplanting; then $20 \%$ of the total $\mathrm{N}$ was applied as tillering fertilizer on June 29 and as booting fertilizer on July 29, respectively. Other fertilizers applied were $54 \mathrm{~kg} \mathrm{P}_{2} \mathrm{O}_{5} \mathrm{ha}^{-1}$ (as calcium phosphate) and $67.5 \mathrm{~kg} \mathrm{~K}_{2} \mathrm{O} \mathrm{ha}^{-1}$ (as potassium chloride), incorporated one day before transplanting as basal fertilizer.

All plots were surrounded by consolidated bunds lined with plastic sheets installed to a depth of $0.3 \mathrm{~m}$ to prevent seepage between plots. Land preparation for both TF and SRI was the same, with wet tillage and harrowing. Seedlings of 13 days age for SRI and 20 days age for TF were transplanted with one seedling per hill. Transplanting spacing between hills was different: $25 \mathrm{~cm}$ $\times 30 \mathrm{~cm}$ for SRI, and $25 \mathrm{~cm} \times 17 \mathrm{~cm}$ for TF; plant populations, respectively, were 13.3 and $23.5 \mathrm{~m}^{-1}$. A japonica rice variety was used (Bing 98110) transplanted on 13 May and harvested on 13 October.

TF plots were continuously flooded with $2-10 \mathrm{~cm}$ water depth except at the end of the tillering stage, when plots were drained 7 days before harvest. SRI plots were kept saturated the first week after transplanting; thereafter they were maintained in a moist condition without standing water covering the field until 15 days after panicle initiation when a thin layer $(2 \mathrm{~cm})$ of water was maintained. Each main plot was irrigated separately, with water supplied every 3-7 days, depending on ambient temperature affecting evapotranspiration. Irrigation water was provided from a tap to a depth of $2 \mathrm{~cm}$ each time, as measured by a plastic ruler inserted into the plot.

\subsection{Ammonia Sampling and Chemical Analysis}

Ammonia volatilization from soil in rice field was determined by venting method, and the instrument used is shown in Figure 1 [17]. The diameter and height of the

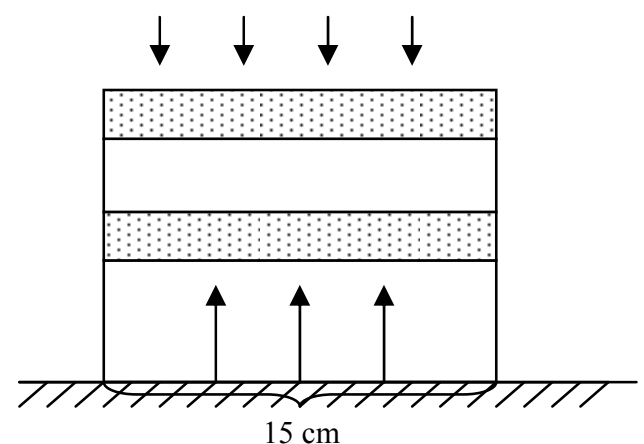

Figure 1. Design of instrument for collecting ammonia volatilization from the soil surface. 
PVC cylinder was $15 \mathrm{~cm}$ and $30 \mathrm{~cm}$, respectively. Two pieces of sponge $(2.5 \mathrm{~cm}$ thickness) were installed in a PVC cylinder after being immersed with $15 \mathrm{ml}$ glycerol phosphoric acid $(5 \%, \mathrm{v} / \mathrm{v}$, phosphoric acid and $4 \%, \mathrm{v} / \mathrm{v}$, glycerol). The base of the cylinder was inserted $2 \mathrm{~cm}$ into the soil. The lower sponge was $20 \mathrm{~cm}$ distance of the soil surface and used to absorb ammonia volatilized from the soil surface in the cylinder, and the upper sponge was $5.0 \mathrm{~cm}$ distance of the lower sponge and was to absorb ammonia from outside the cylinder and to prevent its absorption by the lower sponge. After fertilizer was applied, the instrument was installed immediately. Within one week after fertilization, the lower sponge was replaced with a new one after $24 \mathrm{~h}$, and after one week, the lower sponge was replaced with a new one after $48 \mathrm{~h}$. The upper sponge was changed every 3 days. The sponges were extracted with $300 \mathrm{ml}$ of $1 \mathrm{~mol} / \mathrm{L}$ $\mathrm{KCl}$ for $1 \mathrm{~h}$ and analyzed $\mathrm{N}$ content by nitrogen auto analyzer (KDN-102C, China).

At maturity, grain yield was determined as the mean of two 5- $\mathrm{m}^{2}$ samples per sub-plot. Plant samples were taken from 5 hills in every sub-plot to determine the amount of aboveground biomass after the samples were dried at $70^{\circ} \mathrm{C}$. Total $\mathrm{N}$ content was determined using the standard Kjeldahl method.

Agronomic $\mathrm{N}$ use efficiency (ANUE, $\mathrm{kg}$ grain $\mathrm{kg} \mathrm{N}$ applied $^{-1}$ ) was calculated from the difference in grain yields $\mathrm{N}$ between fertilized and unfertilized plots divided by the $\mathrm{N}$ application rate. Partial factor productivity of applied $\mathrm{N}$ (PFP, $\mathrm{kg}$ grain $\mathrm{kg} \mathrm{N}$ applied ${ }^{-1}$ ) was calculated as grain yields divided by the $\mathrm{N}$ application rate.

\subsection{Statistical Analysis}

Analysis of variance (ANOVA) was performed on a split-plot design with cultivation methods as the main factor and $\mathrm{N}$ rates as the sub-factor. When cultivation methods or $\mathrm{N}$ rates effects were significant, pair-wisetesting with the $t$-test was done between cultivation methods or among $\mathrm{N}$ rates. The level of confidence was set at $95 \%$. Statistical procedures were conducted using the data processing system software [18].

\section{RESULTS}

\subsection{Effects of SRI and N Fertilizer Rate on Grain Yield}

Grain yield ranged from 5.6 to $6.9 \mathrm{t} \mathrm{ha}^{-1}$ under SRI, and from 4.0 to $6.1 \mathrm{t} \mathrm{ha}^{-1}$ under TF (Table 1). The maximum grain yield was at $\mathrm{N} 1$ level $\left(80 \mathrm{~kg} \mathrm{~N} \mathrm{ha}^{-1}\right)$ under SRI and at $\mathrm{N} 2$ level (160 $\left.\mathrm{kg} \mathrm{N} \mathrm{ha}^{-1}\right)$ under TF. SRI significantly increased grain yield compared to $\mathrm{TF}$ in N0 and N1; however, there was no significant difference at N2 and $\mathrm{N} 3$ levels. Over the whole range of $\mathrm{N}$ application rates, SRI gave on average yields $22 \%$ higher than TF using much less irrigation water.

\section{2. $\mathrm{N}$ Uptake by Rice and Distribution in Different Organs}

SRI plants had greater $\mathrm{N}$ uptake than TF plants (Figure 2). $\mathrm{N}$ uptake by rice ranged from 308.8 to $596.4 \mathrm{mg}$

Table 1. Grain yield of rice under SRI and TF with $\mathrm{N}$ rates $(n=3)$.

\begin{tabular}{|c|c|c|c|}
\hline \multirow{2}{*}{$\mathrm{N}\left(\mathrm{kg} \mathrm{ha}^{-1}\right)$} & \multicolumn{3}{|c|}{ Grain yield $\left(\mathrm{t} \mathrm{ha}^{-1}\right)$} \\
\hline & TF & SRI & Difference \\
\hline 0 (N0) & $4.0 \mathrm{~b}$ & $5.6 \mathrm{~b}$ & $1.6^{* *}$ \\
\hline $80(\mathrm{~N} 1)$ & $4.9 \mathrm{a}$ & 6.9 & $2.0^{* *}$ \\
\hline $160(\mathrm{~N} 2)$ & $6.1 \mathrm{a}$ & 6.7 & $0.6^{\mathrm{ns}}$ \\
\hline $240(\mathrm{~N} 3)$ & 5.7 & 6.1 & $0.4^{\mathrm{ns}}$ \\
\hline \multicolumn{4}{|l|}{ Analysis of variance } \\
\hline Cultivation & & & \\
\hline $\mathrm{N}$ level & & & \\
\hline Cultivation $\times \mathrm{N}$ rates & & & \\
\hline
\end{tabular}

Notes: Values followed by the same letter in a column are not significantly different at the $5 \%$ level by LSD; ns $=$ not significant; $*=P<$ $0.05 ; * *=P<0.01$ between SRI and TF.

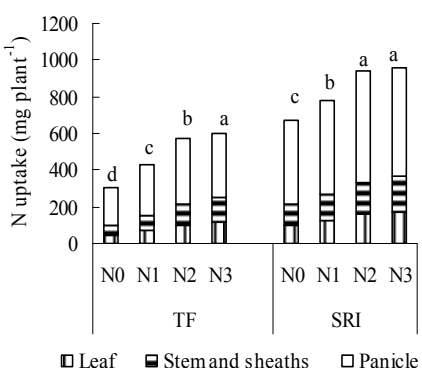

(a)

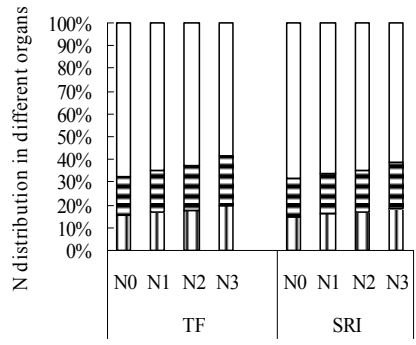

(b)

Notes: The same letter within different $\mathrm{N}$ rate under SRI and TF are not significantly different by LSD at the 0.05 level.

Figure 2. $\mathrm{N}$ uptake and distribution in stem and sheaths, leaf and panicle at maturing stage. 
plant $^{-1}$ under TF and ranged from 673.1 to $957.4 \mathrm{mg}$ plant $^{-1}$ under SRI management. SRI significantly increased total $\mathrm{N}$ uptake by individual plants, and $\mathrm{N}$ uptake by leaves, stem-sheaths and panicle irrespective of the $\mathrm{N}$ application rate compared to $\mathrm{TF}$. Total $\mathrm{N}$ per plant, $\mathrm{N}$ uptake by leaves and stem-sheaths increased with increased $\mathrm{N}$ application rate; however, maximum amount of $\mathrm{N}$ uptake in panicle was in $\mathrm{N} 2$ level and then decreased under both SRI and TF when $\mathrm{N}$ applications were higher (Figure 2(a)). The ratio of $\mathrm{N}$ in leaves and stem-sheaths to total $\mathrm{N}$ uptake increased with increased $\mathrm{N}$ rate, while the ratio of $\mathrm{N}$ in panicle to total $\mathrm{N}$ uptake decreased (Figure 2(b)).

\subsection{Effects of SRI and N Fertilizer Rate on Nitrogen Use Efficiency}

The interactive effects of cultivation methods and $\mathrm{N}$ rate on ANUE and PFP were significantly different. Values of agronomic $\mathrm{N}$ use efficiency (ANUE) ranged from 7.1 to $12.6 \mathrm{~kg}_{\text {grain }} \mathrm{kg}^{-1} \mathrm{~N}$ applied under $\mathrm{TF}$, and from 2.1 to $15.7 \mathrm{~kg}_{\text {grain }} \mathrm{kg}^{-1} \mathrm{~N}$ applied under SRI (Table 2). Values for partial factor productivity of applied $\mathrm{N}$ (PFP) ranged from 23.9 to $61.3 \mathrm{~kg}$ grain $\mathrm{kg}^{-1} \mathrm{~N}$ applied under $\mathrm{TF}$, and 25.5 to $86.0 \mathrm{~kg}$ grain $\mathrm{kg}^{-1} \mathrm{~N}$ applied under SRI. Compared with TF, ANUE with SRI methods was higher in $\mathrm{N} 1$ and lower in N2 and N3. However, PFP under SRI was higher than $\mathrm{TF}$ in each $\mathrm{N}$ treatment. $\mathrm{N}$ application and cultivation methods significantly influenced ANUE and PFP.

\subsection{Effects of SRI and N Fertilizer Rate on Ammonia Volatilization}

Changes in ammonia volatilization rate at basal, tillering and booting stages under both SRI and TF treatments were similar (Figure 3), and the highest rate appeared 4 days after basal and tillering fertilization and 3 days after booting fertilization, respectively. The total amount of ammonia volatilization loss ranged from 2.14 to 13.13 $\mathrm{kg} \mathrm{ha}^{-1}$ under TF and from 3.14 to $16.23 \mathrm{~kg} \mathrm{ha}^{-1}$ under SRI, respectively. This accounted for $3.2-5.3 \%$ and $3.9-5.8 \%$ of the total $\mathrm{N}$ applied (Table 3). Total ammonia volatilization loss increased by $23.6 \sim 46.7 \%$ with SRI compared to TF. $\mathrm{N}$ fertilizer input significantly led to higher ammonia volatilization rate and loss than the $\mathrm{N}$-zero controls for both TF and SRI.

\section{DISCUSSION}

\subsection{Grain Yield}

Compared to TF, SRI significantly increased grain yield. This may be attributed to the increase of the number of

Table 2. Agronomic $\mathrm{N}$ use efficiency (ANUE, $\mathrm{kg}$ grain $\mathrm{kg} \mathrm{N}_{\text {applied }}^{-1}$ ) and partial factor productivity of applied N (PFP, $\mathrm{kg}$ grain $\mathrm{kg} \mathrm{N}$ applied $\left.{ }^{-1}\right)$ under SRI and TF with $\mathrm{N}$ rate $(\mathrm{n}=3)$.

\begin{tabular}{|c|c|c|c|c|c|c|c|c|c|c|}
\hline \multirow{3}{*}{$\frac{\mathrm{N}\left(\mathrm{kg} \mathrm{ha}^{-1}\right)}{80(\mathrm{~N} 1)}$} & \multicolumn{5}{|c|}{ ANUE } & \multicolumn{5}{|c|}{ PFP } \\
\hline & \multicolumn{2}{|l|}{ TF } & \multicolumn{2}{|l|}{ SRI } & \multirow{2}{*}{$\begin{array}{c}\text { Difference } \\
5.1^{* *}\end{array}$} & \multicolumn{2}{|l|}{ TF } & \multicolumn{2}{|l|}{ SRI } & \multirow{2}{*}{$\begin{array}{l}\text { Difference } \\
24.7^{* *}\end{array}$} \\
\hline & 10.6 & $\mathrm{a}$ & 15.7 & $\mathrm{a}$ & & 61.3 & a & 86.0 & $\mathrm{a}$ & \\
\hline $160(\mathrm{~N} 2)$ & 12.6 & $\mathrm{a}$ & 7.0 & $\mathrm{~b}$ & $-5.6^{* *}$ & 37.9 & $\mathrm{~b}$ & 42.1 & $\mathrm{~b}$ & $4.2^{* *}$ \\
\hline $240(\mathrm{~N} 3)$ & 7.1 & $\mathrm{~b}$ & 2.1 & $\mathrm{c}$ & $-5.0^{* *}$ & 23.9 & $\mathrm{~b}$ & 25.5 & $\mathrm{c}$ & $1.6^{\mathrm{ns}}$ \\
\hline \multicolumn{3}{|c|}{ Analysis of variance } & \multicolumn{3}{|c|}{ ANUE } & \multicolumn{5}{|c|}{ PFP } \\
\hline \multicolumn{3}{|c|}{ Cultivation } & \multicolumn{3}{|c|}{$*$} & \multicolumn{5}{|c|}{$* *$} \\
\hline \multicolumn{3}{|c|}{$\mathrm{N}$ level } & \multicolumn{3}{|l|}{$* *$} & \multicolumn{5}{|c|}{$* *$} \\
\hline \multicolumn{3}{|c|}{ Cultivation $\times \mathrm{N}$ rate } & \multicolumn{3}{|l|}{$* *$} & \multicolumn{5}{|c|}{$* *$} \\
\hline
\end{tabular}

Table 3. Ammonia volatilization losses after $\mathrm{N}$ fertilizer application at basal, tillering and booting stages $\left(\mathrm{kg} \mathrm{N} \mathrm{ha}^{-1}\right)(\mathrm{n}=3)$.

\begin{tabular}{|c|c|c|c|c|c|}
\hline ultivation & $\mathrm{N}$ rates & Basal fertilizer & Tillering fertilizer & Booting fertilizer & Total $\mathrm{NH}_{3}$ loss \\
\hline \multirow[t]{4}{*}{$\mathrm{TF}$} & No & $1.02 \mathrm{a}$ & $0.80 \quad \mathrm{a}$ & $0.32 \mathrm{a}$ & $2.14 \mathrm{a}$ \\
\hline & N1 & 3.77 & 1.58 & 1.08 & $6.44 \mathrm{~b}$ \\
\hline & $\mathrm{N} 2$ & $4.91 \mathrm{c}$ & 3.03 & 1.84 & $9.78 \mathrm{c} \quad(4.77)$ \\
\hline & N3 & 6.33 & 4.19 & 2.61 & $13.13 \mathrm{~d} \quad(4.58)$ \\
\hline \multirow[t]{4}{*}{ SRI } & N0 & 1.38 & 1.03 & 0.72 & $3.14 \mathrm{a}$ \\
\hline & N1 & 4.22 & $1.98 \mathrm{~b}$ & 1.67 & $7.88 \mathrm{~b} \quad(5.93)$ \\
\hline & $\mathrm{N} 2$ & 6.06 & 3.65 & 2.48 & $12.19 \mathrm{c} \quad(5.66)$ \\
\hline & N3 & 7.78 & $5.04 \mathrm{~d}$ & 3.41 & $16.23 \mathrm{~d} \quad(5.45)$ \\
\hline
\end{tabular}

Notes: Values followed by the same letter within one column are not significantly different by LSD at the 0.05 level under the same cultivation system. The number in parentheses indicated the percentage of the amount of applied N. 


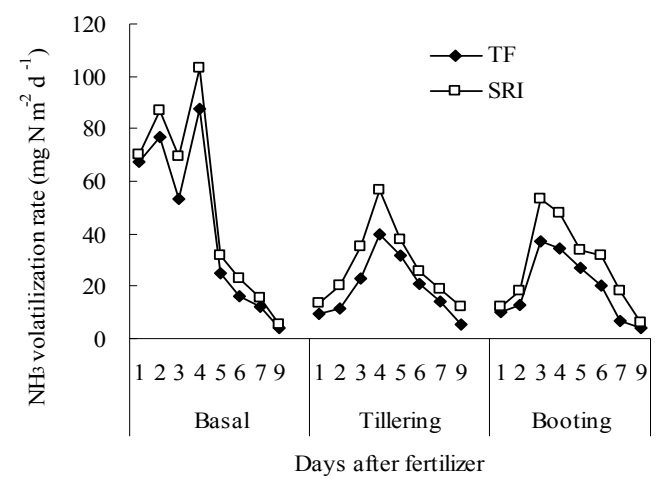

Figure 3. Average ammonia volatilization rates with four $\mathrm{N}$ rates after $\mathrm{N}$ fertilizer application at basal (May 19), tillering (June 29) and booting (July 29) stage under SRI and TF.

tiller and effective panicles and higher chlorophyll [19]; furthermore, the leaf $\mathrm{N}$ content (chlorophyll SPAD) is closely related to photosynthetic rate and biomass production [20]. Another explanation was SRI had greater root activity and delayed root and leaf senescence during later growth stages according to research [21,22].

The interactive effects on grain yield between cultivation and $\mathrm{N}$ rate was significant. The yield-increasing effect with SRI was affected by $\mathrm{N}$ fertilizer applied, and the maximum yield difference in grain yield was in N1 $(80$ $\mathrm{kg} \mathrm{h}^{-1}$ ) level, and there were no significantly difference at N2 $\left(160 \mathrm{~kg} \mathrm{ha}^{-1}\right)$ and N3 $\left(240 \mathrm{~kg} \mathrm{ha}^{-1}\right)$ level. These results were explained that SRI plots likely had higher N uptake from the indigenous supply due to the changes in the environment for growing rice and had a better root system under SRI. The SRI changes the environment of rice growth from anaerobic to aerobic soil conditions, with no standing water during the vegetative growth period and only a thin layer of water on the field $(1-2 \mathrm{~cm})$ from panicle initiation until 10-15 days before harvest. These practices may affect the structure and functioning of soil biota, nutrient status and cycling, and root system. Bonkowski [23] indicated that under more aerobic soil conditions, there will be larger populations of soil microbes that contribute to biological processes for supplying $\mathrm{N}$ needs of plants. Hence, yield increase with SRI should not rely on increased nitrogen application, the moderate water requirements and nitrogen management under SRI should be paid more attention.

\subsection{N Uptake and Utilization}

$\mathrm{SRI}$ increased the ratio of panicle $\mathrm{N}$ among four $\mathrm{N}$ fertilizer levels compared with TF. ANUE and PFP both decreased with increased $\mathrm{N}$ application rates, while the ANUE in N2 $\left(80 \mathrm{~kg} \mathrm{ha}^{-1}\right)$ level was at a maximum under SRI. These results showed that SRI methods benefited nitrogen uptake by rice and could promote the transfer of nitrogen in leaves and stem-sheaths to the panicle, while high-levels of nitrogen may have resulted just in luxury uptake of $\mathrm{N}$ by rice. These results were supported by other research [24,25]. Abha and Salokhe [26] indicated that younger seedlings performed better than older seedlings when transplanted into either flooded or nonflooded soils with greater uptake of nitrogen and manganese than older seedlings. Higher available $\mathrm{N}$ in soil resulting higher $\mathrm{N}$ uptake from soil under SRI management compared to TF due to increased root biomass and activity with SRI $[21,25]$, while higher soil microbial activity contributed to soil processes for supplying plants' nitrogen needs [23]. This was supported by Rupela et al. [27] who reported that microbial biomass N, microbial biomass carbon, dehydrogenase, root mass, root density and root volume were higher under SRI than in flooded rice.

\subsection{Ammonia Vocalization Loss}

$\mathrm{N}$ fertilizer significantly increased ammonia volatilization loss of both SRI and TF, and ammonia volatilization loss increased generally with higher $\mathrm{N}$ fertilizer rate. The greatest loss of ammonia volatilization for both SRI and TF was at the basal stage, next was at tillering stage, and the smallest loss was at booting stage. This may suggest that largest ammonia volatilization was affected by high $\mathrm{N}$ fertilizer input and the different ratios of $\mathrm{N}$ fertilizer applied at basal, tiller and booting stage. Higher ammonia volatilization loss at basal stage was due to the root systems having little sink capacity for $\mathrm{N}$ so early in the crop cycle [28], especially with transplanting young seedlings (about 15 days old) in our study. Though same amount of $\mathrm{N}$ fertilizer was applied at tillering and booting stage, there is less loss at booting stage than tillering stage, suggesting that at booting stage, well-developed canopies reduced the ammonia volatilization loss due to lower ammonia gas concentrations and restricted air movement. Therefore, such results indicated that optimum ratio of $\mathrm{N}$ fertilizer at different stages was important to reduce ammonia volatilization losses.

Ammonium volatilization is consistently higher under SRI than TF, suggesting a potentially more intensive $\mathrm{N}$ loss under SRI, though with no significant difference between both. This may suggest that non-flooded rice led to higher concentration of $\mathrm{NH}_{4}{ }^{+}$in the soil and soil solution than with flooding, which may have benefited the long-term nitrogen availability for rice growth under SRI. There was a significant correlation between $\mathrm{NH}_{4}{ }^{+}$ in the soil, soil solution and ammonia volatilization loss [29]. Cui et al. [30] have reported that ammonia volatilization loss under water-saving irrigation was higher by $22.9 \%$ than with continuous flooding. Moreover, transplanting young seedlings with wider spacing under SRI could be another reason to create higher ammonia volatilization loss.

\section{CONCLUSIONS}

Our results showed that the highest grain yield of rice, 
ANUE and PFP were achieved at a relatively low rate of $\mathrm{N}$ fertilization $\left(80 \mathrm{~kg} \mathrm{ha}^{-1} \mathrm{~N}\right)$ under the system of rice intensification (SRI). SRI significantly increased $\mathrm{N}$ uptake during rice growth and promoted $\mathrm{N}$ translocation to the panicle. Though SRI caused higher ammonium volatilization loss than TF, the percentage of loss at $80 \mathrm{~kg}$ $\mathrm{ha}^{-1} \mathrm{~N}$ is at the similar magnitude to that at higher $\mathrm{N}$ fertilizer input rates $\left(160 \sim 240 \mathrm{~kg} \mathrm{ha}^{-1}\right)$, which were characterized by the decreasing grain yield and $\mathrm{N}$ use efficiency (Tables 1-3). To increase $\mathrm{N}$ use efficiency and to decrease $\mathrm{N}$ losses, as well as to maintain or improve soil fertility for sustainable crop production, research efforts are needed to focus on the effects of SRI on soil fertility and nitrogen management. Due to the increasing fertilizer costs, irrigation water shortages, and growing pollution/environmental problems in the future decades, the current study can help further investigate the different cultivation system and fertilization strategy for the sake of sustainable rice production and soil management at a single-season experiment and long-term purpose.

\section{ACKNOWLEDGEMENTS}

This research was supported by the Key Project of Agricultural Construction Adjustment of Ministry of Agriculture of China (No. 200301-02A), Key Project of Ministry of Science and Technology of China (2008ZX07101-006) and Key Projects in the National Science \& Technology Pillar Program (No. 2008BADA4B03).

\section{REFERENCES}

[1] Cassman, K.G., Peng, S., Olk, D.C., Ladha, J.K., Reichardt, W., Dobermann, A. and Singh, U. (1998) Opportunities for increased nitrogen-use efficiency from improved resource management in irrigated rice systems. Field Crops Research, 56(1-2), 7-39.

[2] Barker, R. and Dawe, D. (2001) The transformation of the Asian rice economy and directions for future research: the need for increased productivity. In: Sombilla, M., Hossain, M. and Hardy, B., Ed., Developments in the Asian Rice Economy, International Rice Research Institute, Los Baños, 1-30.

[3] FAO. (2004) FAO Statistical databases. Food and Agriculture Organization (FAO) of the United Nations, Rome.

[4] Peng, S.B., Buresh, R.J., Huang, J.L., Yang, J.C., Zou, Y.B., Zhong, X.H., Wang, G.H. and Zhang, F.S. (2006) Strategies for overcoming low agronomic nitrogen use efficiency in irrigated rice systems in China. Field Crops Research, 96(1), 37-47.

[5] Qin, S.W., Fan, X.H. and Wang, J.F. (2001) The fertilization technique of five main crops. In: Xu, J.A., Ed., Fertilization and Agricultural Service, in Chinese, Chemical Industry Press, Beijing.

[6] Gao, X.J., Hu, X.F., Wang, S.P., He, B.G. and Xu, S.Y. (2002) Nitrogen losses from flooded rice field. Pedosphere, 12(2), 151-156.

[7] Ghosh, B.C. and Bhat, R. (1998) Environmental hazards of nitrogen loading in wetland rice fields. Environmental
Pollution, 102(1), 123-126.

[8] Barthelmie, R.J. and Pryor, S.C. (1998) Implications of ammonia emissions for the aerosol formation and visibility impairmenta case study from the Lower Fraser Valley, Birtish Columbia. Atmospheric Environment, 32, 345-352.

[9] Van Nguyen, N. and Ferrero, A. (2006) Meeting the challenges of global rice production. Paddy Water Environment, 4, 1-9.

[10] Maclean, J.L., Dawe, D.C., Hardy, B. and Hettel, G.P. (2002) Rice almanac. 3rd Edition, International Rice Research Institute, Los Baños, 253.

[11] FAO. (2001) FAO Statistical databases. Food and Agriculture Organization (FAO) of the United Nations, Rome.

[12] Bouman, B.A.M. and Tuong, T.P. (2001) Field water management to save water and increase its productivity in irrigated rice. Agricultural Water Management, 49(1), 11-30.

[13] Guerra, L.C., Bhuiyan, S.I., Tuong, T.P. and Barker, R. (1998) Producing more rice with less water from irrigated systems. International Rice Research Institute, Los Baños, 1-22.

[14] Tuong, T.P. and Bouman, B.A.M. (2003) Rice production in water-scarce environments. In: Kijne, J.W., Barker, R. and Molden, D., Ed., Water Productivity in Agriculture: Limits and Opportunities for Improvement, CABI Publishing, Wallingford, 53-67.

[15] Stoop, W.A., Uphoff, N. and Kassam, A. (2002) A review of agricultural research issues raised by the system of rice intensification (SRI) from Madagascar: Opportunities for improving farming systems for resource-poor farmers. Agricultural Systems, 71(3), 249-274.

[16] Uphoff, N., Fernandes, E.C.M., Yuan, L.P., Peng, J.M., Rafaralahy, S. and Rabenandrasana, J. (2002) Assessment of the system of rice intensification (SRI). Proceedings of the International Conference, Sanya, 1-4 April 2002, Cornell International Institute for Food, Agriculture and Development (CIIFAD), Ithaca. http://ciifad.cornell.edu./ sri/proccontents.html

[17] Wang, C.H., Liu, X.J., Ju, X.T. and Zhang, F.S. (2002) Field in situ determination of ammonia volatilization from soil: Venting method. Plant Nutrition and Fertilizer Science, 8(2), 205-209.

[18] Tang, Q.Y. and Feng, M.G. (2002) Practical application of statistics analysis and data processing system. Science Press, Bejing.

[19] Zhao, L.M., Wu, L.H., Li, Y.S., Animesh, S., Zhu, D.F. and Uphoff, N. (2010) Comparisons of yield, water use efficiency, and soil microbial biomass as affected by the system of rice. Communications in Soil Science and Plant Analysis, 41(1), 1-12.

[20] Peng, S., Garcia, F.V., Laza, R.C., Sanico, A.C., Visperas, R.M. and Cassman, K.G. (1996) Increased N-use efficiency using a chlorophyll meter on high-yielding irrigated rice. Field Crops Research, 47(2), 243-252.

[21] Xu, F.Y., Ma, J., Wang, H.Z., Liu, H.Y., Huang, Q.L., Ma, W.B. and Ming D.F. (2003) The characteristics of roots and their relation to the formation of grain yield under the cultivation by system of rice intensification (SRI). Hybrid Rice, in Chinese, 18(4), 61-65.

[22] Satyanarayana, A. (2005) System of rice intensification: An innovative method to produce more with less water and inputs. 4th IWMI-Tata Annual Partners' Meeting, 
IRMA, Anand, 24-26 February 2005.

[23] Bonrowski, M. (2004) Protozoa and plant growth: The microbial loop in soil revisited. New Phytologist, 162(3), 616-631.

[24] Chen, H.Z., Zhu, D.F., Rao, L.B., Lin, X.Q. and Zhang, Y.P. (2006) Effects of SRI technique on population quality after heading stage and yield formation in rice. Journal of Huazhong Agricultural University, in Chinese, 25(5), 483-487.

[25] Lu, X.M., Huang, Q. and Liu, H.Z. (2006) Research of some physiological characteristics under the system of rice intensification. Journal of South China Agricultural University, in Chinese, 27, 5-7.

[26] Mishra, A. and Salokhe, V.M. (2008) Seedling charactistics and the early growth of transplanted rice under different water regimes. Experimental Agriculture, 44, 1-19.

[27] Rupela, O.P., Wani, S.P., Kranthi, M., Humayun, P.,
Satyanarayana, A., Goud, V., Gujja, B., Punnarao, P., Shashibhushan, V., Raju, D.J. and Reddy, P.L. (2006) Comparing soil properties of farmers' fields growing rice by SRI and conventional methods. Proceedings of 1 st National SRI Symposium, Worldwide Fund for Nature-ICRISAT, Hyderabad, 17-18 November 2006.

[28] Schnier, H.F. (1995) Significance of timing and method of $\mathrm{N}$ fertilizer application for $\mathrm{N}$-use efficiency in flooded tropical rice. Fertilizer Research, 42(1-3), 129-138.

[29] Song, Y.S., Fan, X.H., Lin, D.X., Yang, L.Z. and Zhou, J.M. (2004) Investigation on ammonia loss from the flooded rice field in Taihu region and its influencing factors. Acta Pedologica Sinica, in Chinese, 41(2), 265-269.

[30] Cui, Y.L., Li, Y.H., Lv, G.A. and Sha, Z.Y. (2004) Nitrogen movement and transformation with different water supply for paddy rice. Advances in Water Science, in Chinese, 15(3), 280-285. 